\title{
The Dimroth rearrangement of 1,2,3-triazoles in the synthesis of anion receptors based on calix[4]arenas
}

\author{
Yury Yu. Morzerin,* Tatiana A. Pospelova, Tatiana V. Gluhareva, and Anatoly I. Matern \\ Department of Technology for Organic Synthesis, TOSLab, the Urals State Technical University \\ UPI19, Mira str., 620002 Ekaterinburg, Russia \\ E-mail: morjerine@htf.ustu.ru
}

Dedicated to Professor Oleg N. Chupakhin on the occasion of his $70^{\text {th }}$ birthday

(received 20 July 04; accepted 18 Aug 04; published on the web 27 Aug 04)

\begin{abstract}
Reaction of tetrakis-(azidosulfonyl)calix[4]arenes with 2-cyanoacetamides afforded the product of the Dimroth rearrangement, namely tetrakis-(1,2,3-triazole-5-aminosulfonyl) calix[4]arenes. The complexation of the 1,2,3-triazolesulfonamide calixarene hybrids with anions was studied by NMR titration, and association constants were determined.
\end{abstract}

Keywords: Calix[4]arenes, anion-receptors, 1,2,3-triazoles, Dimroth rearrangement

\section{Introduction}

Calix[4]arenes ${ }^{1,2}$ are macrocyclic compounds which are used widely in supramolecular chemistry for the construction of various receptors for the complexation of charged or neutral molecules. Their unique three-dimensional structures with almost unlimited derivatization abilities, and the tunable shape of the molecules, make calixarenes ideal candidates for building blocks and/or molecular scaffolds in the design of new and more sophisticated molecules. Whereas cation complexation has been studied extensively for a long time, the recognition of anions $^{3}$ by synthetic receptors based on the calixarenes still remains relatively unexplored. Thus, the introduction of activated amides ${ }^{4}$ into the upper rim of calixarene derivatives, pre-organized in the cone conformation, led to receptors' interacting with anions by hydrogen bonds. Other moieties used frequently for anion recognition are urea, thiourea ${ }^{5}$ and sulfonamide ${ }^{6}$ units. In the present paper we report anion receptors based on 1,2,3-triazole-calixarene hybrids. 


\section{Results and Discussion}

The starting azidosulfonylcalixarene, 1, was obtained in 55\% yield by reaction of chlorosulfonylcalix[4]arene 2 (cone conformation) ${ }^{6}$ with sodium azide. The cycloaddition of arylsulfonyl azides to cyanoacetamides led to 1-arylsulfonyl-5-amine-1,2,3-triazoles: the latter can be transformed by Dimroth rearrangement into $1 \mathrm{H}-5$-arylsulfonylamino-1,2,3-triazole. We have shown that the treatment of azidosulfonylcalix[4] arene 1 with N-phenyl- and N-cyclohexyl2-cyanoacetamides at $40^{\circ} \mathrm{C}$ in solution in the presence of an equivalent of EtONa for $15 \mathrm{~h}$ gave the tetrakis((1H-1,2,3-triazol-5-amine)sulfonyl)calix[4]arenes 3a,b in 38 and 60\% yields, respectively. The ${ }^{1} \mathrm{H}-\mathrm{NMR}$ spectra of $\mathbf{3 a , b}$ indicates the presence of four $\mathrm{NHSO}_{2}$ protons at 6.52 ppm and four NH protons at 10-11 ppm. Reaction under the same conditions of the tosyl azide and N-phenyl-2-cyanoacetamide also led to the product of Dimroth rearrangement, namely $1 \mathrm{H}-$ 5-tosylamino-1,2,3-triazole-4- $N$-phenylcarboxamide, 5.
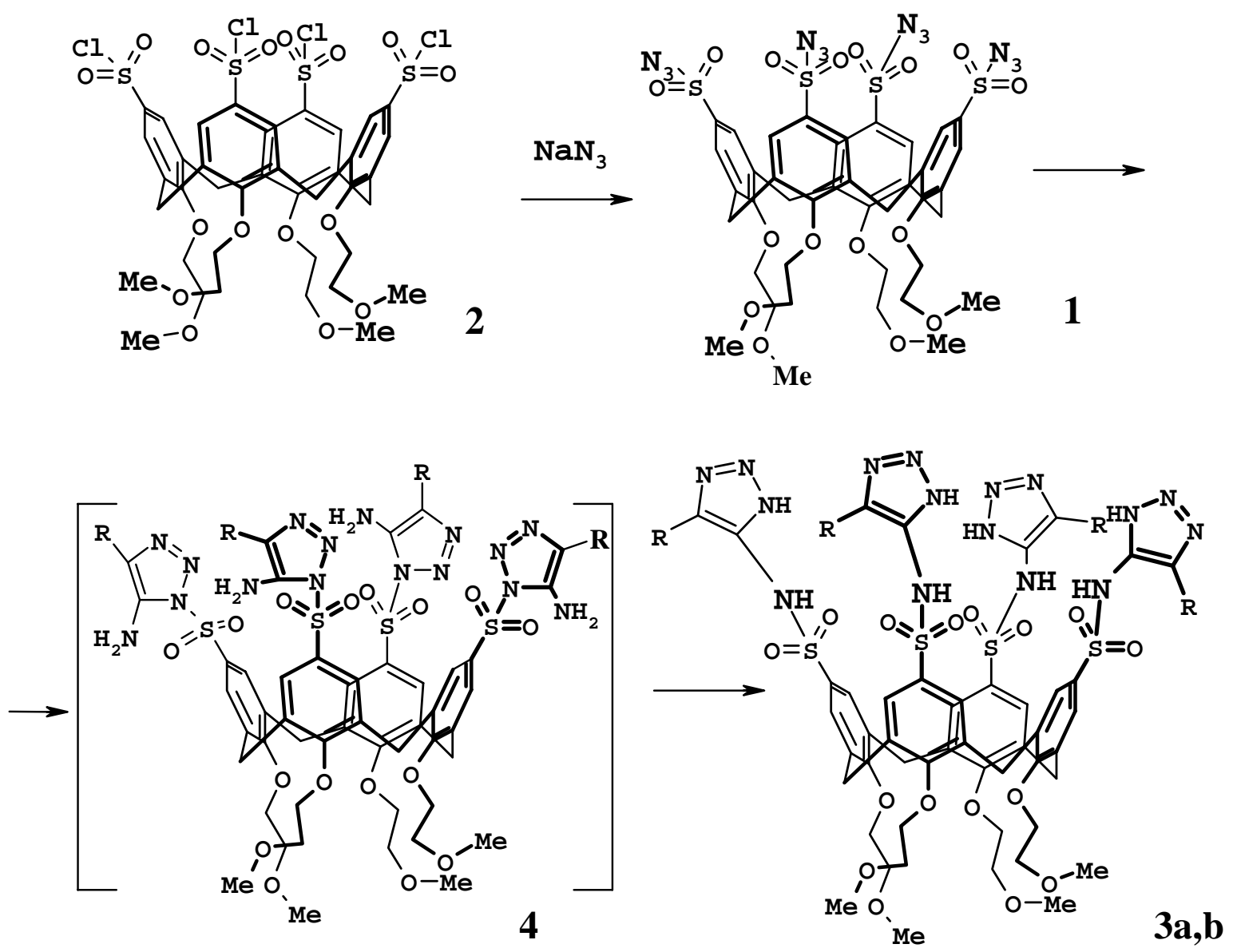

$\mathrm{R}=\mathrm{CONHPh}(\mathbf{a}), \mathrm{CONHC}_{6} \mathrm{H}_{11}$ cyclo (b)

Because the sulfonamide calix[4]arenes are known to form complexes with anions, we proposed the use of tetrakis((1H-1,2,3-triazol-5-amine)sulfonyl)calix[4]arenes 3a,b as neutral 
anion- receptors. A ${ }^{1} \mathrm{H}$ - NMR spectroscopic study revealed that, upon addition of tetrabutylammonium salt to a solution of $\mathbf{3 a}, \mathbf{b}$ in $\mathrm{CDCl}_{3}$, downfield shifts occur in the resonance corresponding to the sulfonamido NH protons (e.g., 8.45 ppm-10.60 ppm, see Figure 1), consistent with the formation of hydrogen bonds. The host-guest complex at 1:1 stoichiometry was determined by Job plots (maxima at mole fractions of 0.5 ). The association constants $K$ of 3a,b (and of reference compounds 5 and 6) with the tetrabutylammonium salt of $\mathrm{NO}_{3}{ }^{-}, \mathrm{Cl}^{-}$have been determined by ${ }^{1} \mathrm{H}-\mathrm{NMR}$ titration experiments, and are summarized in Table 1.

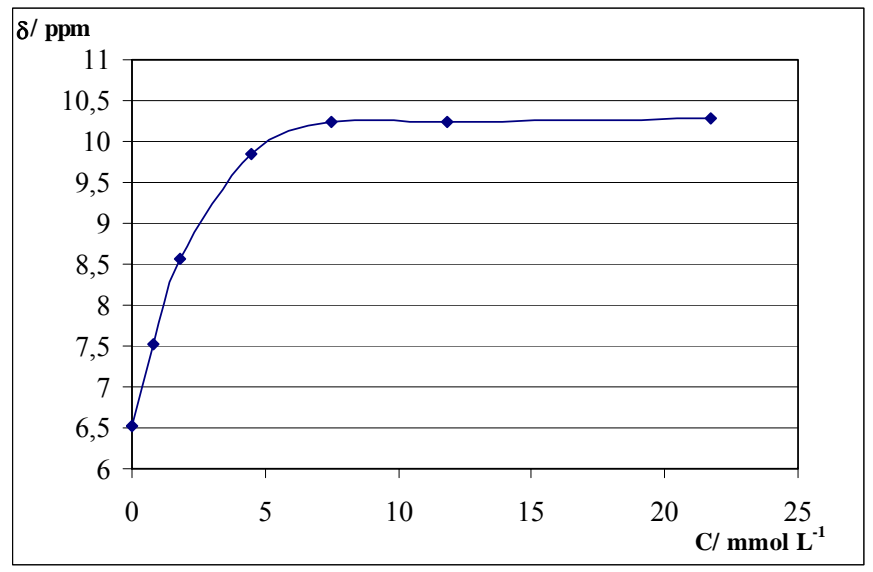

Figure 1. Titration curve for addition of $\mathrm{Bu}_{4} \mathrm{NCl}$ to $3 a$ in $\mathrm{CDCl}_{3}$ at $298^{\circ} \mathrm{C}$.

Table 1. Association constant $\left(\mathrm{K}, \mathrm{M}^{-1}, \mathrm{CDCl}_{3}\right)$ of complexation of $\mathbf{3 a}, \mathbf{b}, \mathbf{5}, \mathbf{6}$ with anions ${ }^{\mathrm{a}}$

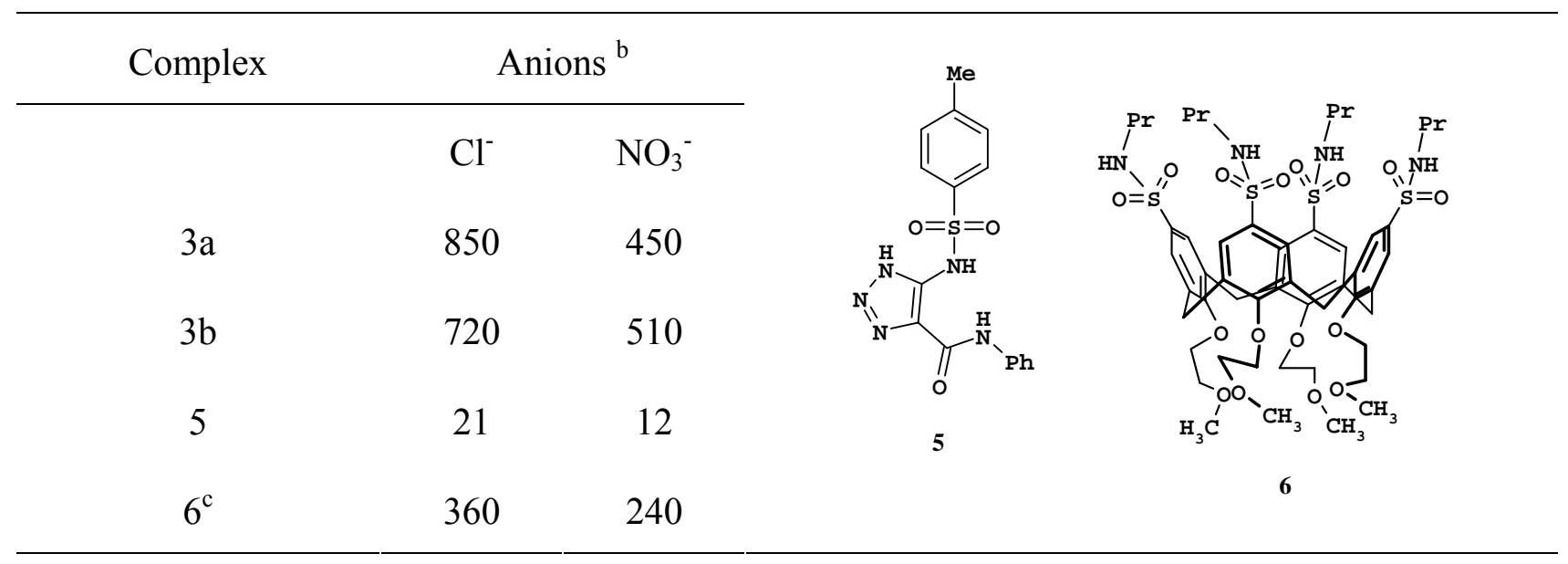

${ }^{\mathrm{a}}$ The error is $<5 \%$. ${ }^{\mathrm{b}}$ The counter-ion is $\mathrm{Bu}_{4} \mathrm{~N}^{+}$. ${ }^{\mathrm{c}}$ Result from ref. 6 .

The influence of the present eight pre-organized binding sites is very clear, from comparing the $\mathrm{K}$ values of 3a,b with that of reference compound 4. Also, the presence of the four NHheterocycle- protons of 3a,b in addition to the four sulfonamide ones in the tetrakis(propylaminosulfonyl)- calix[4]arenes, $5^{4}$, increases $K_{\text {ass }}$. 


\section{Conclusions}

Anion- receptors based on the sulfamoylcalix[4]arenes and 1,2,3-triazoles have been prepared. The key step of this synthesis is the Dimroth rearrangement of a 5-amino-1-arylsulfonyl-1,2,3triazole to a 5-arylsulfonylamino-1H-1,2,3-triazole. The association constants were determined.

\section{Experimental Section}

General Procedures. NMR chemical shifts were recorded with a Bruker WH-250 spectrometer at $250 \mathrm{MHz}, \mathrm{CDCl}_{3}$ solution, and are given in $\delta$ units. All reaction mixtures and products were examined by TLC on DC-Plastikfolen Kieselgel-60 F-254 plates. Melting points are uncorrected. All reagents are commercially available (Aldrich, Acros) and were used without further purification. The calix[4]arenes 2,6 were prepared as described. ${ }^{6}$

25,26,27,28-Tetrakis(methoxyethoxy)-5,11,17,23-tetrakis(azidosulfonyl)calix[4]arene (1). A mixture of chlorosulfonyl calix[4]arenes $2(1.16 \mathrm{~g}, 1 \mathrm{mmol})$ and sodium azide $(0.65 \mathrm{~g}, 10 \mathrm{mmol})$ in $50 \mathrm{ml}$ ethanol was stirred at room temperature for $4 \mathrm{~h}$. The precipitate was filtered off, and the ethanol removed under vacuum at $35^{\circ} \mathrm{C}$. To the residue was added $\mathrm{CH}_{2} \mathrm{Cl}_{2}(50 \mathrm{ml})$, the solution washed with water $(4 \times 100 \mathrm{ml})$, and the solvent removed under vacuum at $35^{\circ} \mathrm{C}$. Yield $55 \%$, m.p. $137^{\circ} \mathrm{C}$ (decomp.) ${ }^{1} \mathrm{H}-\mathrm{NMR}\left(\mathrm{CDCl}_{3}\right), \delta 7.54(8 \mathrm{H}, \mathrm{s}, \mathrm{ArH}), 5.13(4 \mathrm{H}, \mathrm{d}, \mathrm{J}=3.7 \mathrm{~Hz}, 4 \mathrm{xCHAr}), 3.38$ $\left(8 \mathrm{H}, \mathrm{t}, \mathrm{J}=4.4 \mathrm{~Hz}, 4 \mathrm{xOCH}_{2}\right), 3.80\left(8 \mathrm{H}, \mathrm{t}, \mathrm{J}=4.4 \mathrm{~Hz}, 4 \mathrm{xOCH}_{2}\right), 3.56(4 \mathrm{H}, \mathrm{d}, \mathrm{J}=13.7 \mathrm{~Hz}, 4 \mathrm{xCHAr})$, $3.33(12 \mathrm{H}, \mathrm{s}, 4 \mathrm{xOMe})$. Anal. Calc. for $\mathrm{C}_{40} \mathrm{H}_{44} \mathrm{~N}_{12} \mathrm{O}_{16} \mathrm{~S}_{4}, \mathrm{C} 44.60, \mathrm{H} 4.12$, N 15.60, S 11.91 . Found: C 44.37, H 3.98, N 16.00, S 11.60\%.

25,26,27,28-Tetrakis(methoxyethoxy)-5,11,17,23-tetrakis( $N$-(4- $N$-phenylcarbamoyl- $1 H$ 1,2,3-triazol-4-yl)sulfamoyl)calix[4]arene (3a). To a mixture of the calix[4]arene 1 (119 mg, $0.1 \mathrm{mmol})$ and N-phenyl-2-cyanoacetamide $(66 \mathrm{mg}, 0.4 \mathrm{mmol})$ in $5 \mathrm{ml}$ ethanol, was added sodium ethoxide ( $32 \mathrm{mg}, 40.4 \mathrm{mmol}$ ), and the reaction mixture was stirred at $40^{\circ} \mathrm{C}$ for $15 \mathrm{~h}$. The precipitate was filtered and recrystallized from ethanol. Yield 55\%. mp $249^{\circ} \mathrm{C}$ decomp. ${ }^{1} \mathrm{H}-\mathrm{NMR}$ $\left(\mathrm{CDCl}_{3}, \delta, \mathrm{ppm}\right): 10.5-12.0$ (4H, br., $\left.\mathrm{NH}\right), 10.23$ (4H, br. s, NH), 7.0-8.0 (28H, m, ArH), 6.52 $(4 \mathrm{H}, \mathrm{s}, \mathrm{NH}), 5.10(4 \mathrm{H}, \mathrm{d}, \mathrm{J}=14.1 \mathrm{~Hz}, 4 \mathrm{xCHAr}), 4.83\left(8 \mathrm{H}, \mathrm{t}, \mathrm{J}=4.3 \mathrm{~Hz}, 4 \mathrm{xOCH}_{2}\right), 3.78(8 \mathrm{H}, \mathrm{t}$, $\left.\mathrm{J}=4.3 \mathrm{~Hz}, 4 \mathrm{xOCH}_{2}\right), 3.55(4 \mathrm{H}, \mathrm{d}, \mathrm{J}=14.1 \mathrm{~Hz}, 4 \mathrm{xCHAr}), 3.19(12 \mathrm{H}, \mathrm{s}, 4 \mathrm{xOMe})$. Anal. Calc. for $\mathrm{C}_{76} \mathrm{H}_{76} \mathrm{~N}_{20} \mathrm{O}_{20} \mathrm{~S}_{4}$ : C 53.14, H 4.46, N 16.31, S 7.47. Found: C 53.11, H 4.58, N 16.59, S 7.46\%.

25,26,27,28-Tetrakis(methoxyethoxy)-5,11,17,23-tetrakis( $N$-(4- $N$-cyclohexylcarbamoyl-1H1,2,3-triazol-4-yl)sulfamoyl)calix[4]arene (3b). Yield $0.1 \mathrm{~g}$ (60\%). mp $217^{\circ} \mathrm{C} .{ }^{1} \mathrm{H}-\mathrm{NMR}$ $\left(\mathrm{CDCl}_{3}, \delta, \mathrm{ppm}\right): 10.5-12.0(4 \mathrm{H}, \mathrm{br} ., \mathrm{NH}), 10.20(4 \mathrm{H}$, br. s, $\mathrm{NH}), 7.54(8 \mathrm{H}, \mathrm{s}, \mathrm{ArH}), 6.56(4 \mathrm{H}, \mathrm{s}$, $\mathrm{NH}), 5.13(4 \mathrm{H}, \mathrm{d}, \mathrm{J}=13.7 \mathrm{~Hz}, 4 \mathrm{xCHAr}), 4.38\left(8 \mathrm{H}, \mathrm{t}, \mathrm{J}=4.1 \mathrm{~Hz}, 4 \mathrm{xOCH}_{2}\right), 3.88(8 \mathrm{H}, \mathrm{t}, \mathrm{J}=4.1 \mathrm{~Hz}$, $\left.4 \mathrm{xOCH}_{2}\right), 3.56(4 \mathrm{H}, \mathrm{d}, \mathrm{J}=13.7 \mathrm{~Hz}, 4 \mathrm{xCHAr}), 3.34-3.38(4 \mathrm{H}, \mathrm{m}, \mathrm{CH}), 3.20(12 \mathrm{H}, \mathrm{s}, 4 \mathrm{xOMe})$, 1.2-2.2 (40H, m, CH). Anal. Calc. for $\mathrm{C}_{76} \mathrm{H}_{100} \mathrm{~N}_{20} \mathrm{O}_{20} \mathrm{~S}_{4}$ : C 52.40, H 5.79, N 16.08, S 7.36. Found: C 52.66, H 5.45, N 16.20, S 7.45\%. 
Determination of association constants. The measurements were performed by ${ }^{1} \mathrm{H}-\mathrm{NMR}$ titration experiments in $\mathrm{CDCl}_{3}$ at $298^{\circ} \mathrm{C}$ using a concentration of $4 \mathrm{mM}$ and a varying guest concentration of $0.3-30 \mathrm{mM} .^{4}$ For each $K$ value determination 4-8 different guest concentrations were taken. The chemical shift of the $\mathrm{SO}_{2} \mathrm{NH}$ signal was used as the probe. The $K$ values were calculated by non-linear regression as described in ref. 7 .

\section{Acknowledgments}

This research was made possible in part by grants No. 04-03-96143 and No. 04-03-96104 of the Russian Foundation for Basic Research.

\section{References}

1. Asfari, Z.; Böhmer, V.; Harrowfield, J.; Vicens, J. Calixarenes 2001; Kluwer Academic: Dordrecht, 2001.

2. Rudkevich, D. M. Bull. Chem. Soc. Jpn. 2002, 75, 393.

3. Beer, P.D.; Gale, P.A. Angew. Chem. Int. Ed. 2001, 40, 486.

4. Cameron, B. R.; Loeb, S. J. Chem. Commun. 1997, 573.

5. Stastny, V.; Lhoták, P.; Michlová, V.; Stibor, I.; Sykora, J. Tetrahedron 2002, 58, 7207.

6. Morzherin, Yu.; Rudkevich, D.M.; Verboom, W.; Reinhoudt, D. N. J. Org. Chem. 1993, 58, 7602.

7. De Boer, J. A. A.; Reinhoudt, D. N.; Harkema, S.; van Hummel, G. J.; de Jong, F. J. Am. Chem. Soc. 1982, 104, 4073. 